\title{
Effectiveness of Ozone Gas Application Methods against Combined Multi-Contaminants in Food
}

\author{
Christ D., ${ }^{1,2}$, Savi G. D. ${ }^{1}$, Scussel V. M., ${ }^{1, *}$ \\ ${ }^{1}$ Laboratory of Mycotoxicology and Food Contaminants, Food Science and Technology Department, Center of Agricultural Sciences, \\ Federal University of Santa Catarina, Florianopolis, SC, Brazil \\ ${ }^{2}$ Storage Laboratory and Drying Prototypes Facilities, Technological and Exact Sciences Center, Western State University, Cascavel, PR, \\ Brazil
}

\begin{abstract}
Despite the ozone (known as GRAS - generally recognized as safe) gas treatments published for each food living organism or chemical decontamination, they are not necessarily present or contaminate food individually. Most of the time, they are present all together. Therefore, the most important point, regarding an $\mathrm{O}_{3}$ application method to be chosen is its effectiveness to all contaminants that may be in the target food. Therefore, ozone gas decontamination methods that gather combined multi-contaminants and their effectiveness in food were surveyed. Both, for inactivation of living organisms (insects, mites, fungi, yeasts and bacteria) and degradation of toxic compounds (pesticides and mycotoxins). They are the main need for an effective and comprehensive commercial decontamination application. This review brings details on $\mathrm{O}_{3}$ formation energy sources, its application conditions (concentration / time of exposure), container characteristics (volume / material type / sealed or hermetic) and effectiveness for different food (type / contamination level / batch size/moisture content). From the studies and data reported, ozone has shown to be an efficient green agent for combined multi-decontamination, thus prolonging the food storage and shelf life. It does not cause/produce adverse effects on food quality.
\end{abstract}

Keywords Ozone, Decontamination, Fungi, Mycotoxins, Methodology

\section{Introduction}

The knowledge on ozone $\left(\mathrm{O}_{3}\right)$ gas methods against food multi-contaminants combined, such as living organisms (insects, mites, fungi, yeast, bacteria) and toxic compounds (pesticides, mycotoxins, toxic wastes) is necessary to reach a safe, effective and comprehensive commercial application. $\mathrm{O}_{3}$ has been reported showing its safe decontamination efficiency for raw and processed food, either of high (fruits / fresh vegetables) and low (grain / nuts / pulses) humidity, without leaving residue [1-9].

\subsection{Ozone Gas}

The first information regarding $\mathrm{O}_{3}$ was carried out by the Dutch, van Marum in 1783. The author observed that the air, surrounding an electrostatic machine (during a series of electric sparks application), acquired a sharp and characteristic odor [10]. Schönbein in 1840, reported at the Munich Academy that during the parallel $\mathrm{O}_{2}$ evolution reaction, occurs a second unknown gas production with a pungent smell which was then called ozone (from Greek: ozein meaning smell). In addition, showed that the gas can be

* Corresponding author:

vildescussel_2000@yahoo.co.uk (Scussel V. M.)

Published online at http://journal.sapub.org/fph

Copyright (C) 2017 Scientific \& Academic Publishing. All Rights Reserved formed in certain autoxidation processes (by phosphorus in air presence reaction). However, he also was not able to establish the gas nature or composition [10]. Only, around 16 years later, $\mathrm{O}_{3}$ was then identified as a triatomic allotrope form of $\mathrm{O}_{2}$ by Thomas Andrews, with Peter G. Tait collaboration in 1856 [10]. Their work on gas and liquid phase transitions was able to show that $\mathrm{O}_{3}$ was formed by oxygen atoms. Next, Soret in 1863 established the relationship between $\mathrm{O}_{2}$ and $\mathrm{O}_{3}$ by considering that 3 volumes of $\mathrm{O}_{2}$ produce 2 volumes of $\mathrm{O}_{3}$ [11].

When $\mathrm{O}_{2}$ is broken into individual oxygen atoms, which combine with other $\mathrm{O}_{2}$, the $\mathrm{O}_{3}$ is formed [12]. Its molecule undergoes a spontaneous dissociation (high $\mathrm{O}_{3}$ instability) process, again resulting in $\mathrm{O}_{2}$ formation $[13,14]$. The $\mathrm{O}_{3}$ bluish gas half-life time varies from a few seconds to hours, and its stability depends on different factors, among them, temperature. An increase of $10^{\circ} \mathrm{C}$ results in a reduction of at least $43 \%$ in the $\mathrm{O}_{3}$ half-life [15]. At atmospheric conditions, its half-life is about $30 \mathrm{~min}$ and this reaction proceeds more rapidly at higher temperature and lower pressure [16-19]. Therefore, being an unstable gas, it requires to be produced at its application site, thus reducing costs and risks related to transport and storage [9, 20, 21]. As a very reactive oxidizing agent, $\mathrm{O}_{3}$ has proved effective against a broad spectrum of living organisms and chemicals. It kills bacteria, fungi, yeasts, viruses and protozoa [17, 18, 22-28] storage pests, such as insects \& mites. It also has the potential to degrade 
mycotoxins, pesticides and toxic chemical wastes [2, 7-9, 26, 29-34].

It has been considered by different international organizations and countries regulations as GRAS (generally recognized as safe) and can be utilized in direct contact to drinking water and food (the US Food and Drug Administration - FDA \& Agriculture Department - USDA, Food Agriculture Organization - FAO and World Health Organization - WHO) [9]. Apart from those international institutions and countries (Europe, China; Japan, Australia, Brazil) ministries of agriculture and health, recognizing the use of $\mathrm{O}_{3}$ for food, there is a wide supporting literature attesting the benefits of ozonation as an efficient method/procedure for food (raw \& processed) living organisms inactivation and chemicals degradation [9].

\subsection{Ozone Production Energy Sources}

The gas can be produced either, naturally and freely in the stratosphere through the interaction of solar ultraviolet radiation with the molecular $\mathrm{O}_{2}$ [35], or artificially through electric dischargers reaction or ionizing radiation, being the corona discharger apparatus, the most known and utilized in different food processes [9]. The gas production, when performed by the electric discharge process (corona discharger), occurs through the tunnel gap between 2 electrodes subjected to a high potential difference of approximately $1000 \mathrm{~V}$ (electrode A: high voltage; electrode $\mathrm{B}$ : ground) (Figure 1). The $\mathrm{O}_{3}$ then, is generated by the passage of air or pure $\mathrm{O}_{2}$ between the electrodes. Thus, when electrons have enough energy to dissociate the $\mathrm{O}_{2}$ molecules, collisions among them begin to occur, causing the dissociation of $\mathrm{O}_{2}$ with subsequent $\mathrm{O}_{3}$ formation $[9,26,36]$. There are available different types, sizes and potential intensities $\mathrm{O}_{3}$ generators (ozonisers); from small sizes/low capacity to large sizes/high capacity. Some of them can be portable, installed along the industries processing plants or mobile (that can be hired by different grain storage unities) $[9,37]$.

\section{Ozone Multi-contaminants Inactivation and/or Degradation in Raw and Processed Food}

Despite the $\mathrm{O}_{3}$ treatment findings and publications for each food living organisms or chemical contaminants published, they are not necessarily present or contaminate food individually. Most of the time, they are present all together, such as combinations of fungi / mycotoxins \& pesticides; or insects / mites / bacteria \& insecticides. Therefore, the most important point, regarding an $\mathrm{O}_{3}$ application method to be chosen (right concentration / exposure time / whether gas or aqueous $\mathrm{O}_{3}$ / efficiency), is its effectiveness (inactivation and/or degradation) to all contaminants that may be in the target food. Indeed, there has been quite a broad list of publications on $\mathrm{O}_{3}$ gas application in food, most of them reports its influence on individual contaminants though [9]. Fortunately, there are studies reporting the $\mathrm{O}_{3}$ effectiveness to multiple contaminants present in same food at different combinations such as bacteria, yeast \& fungi; fungi \& insects; fungi \& mycotoxins; fungi, mycotoxins \& insects and fungi \& pesticides [2, 7-9, 15, 25, 38-46]. The gas concentrations; exposure time versus food contamination levels and the groups (cereals / pulses / nuts / fruits / spices) have been also detailed including the percentage of reduction. Some of them do inform their effectiveness related to the initial (bacteria / yeast /fungi load and toxin level - whether high or just above the maximum limit allowed) and final (after gas treatment) food contamination, which are quite important information, to achieve the $\mathrm{O}_{3}$ method concentration effectiveness [9].

We report here studies on $\mathrm{O}_{3}$ gas application against multi-contaminant combinations which can be more effectively utilized on the food area against both groups: living organisms and toxic compounds. Table 1 shows the treatments against the multi-contaminants (type / concentration / time of exposure / inhibition rate/percentage) reported in the food area. Note: due to the variations on unities utilized by different authors, they (unities) were kept as reported.

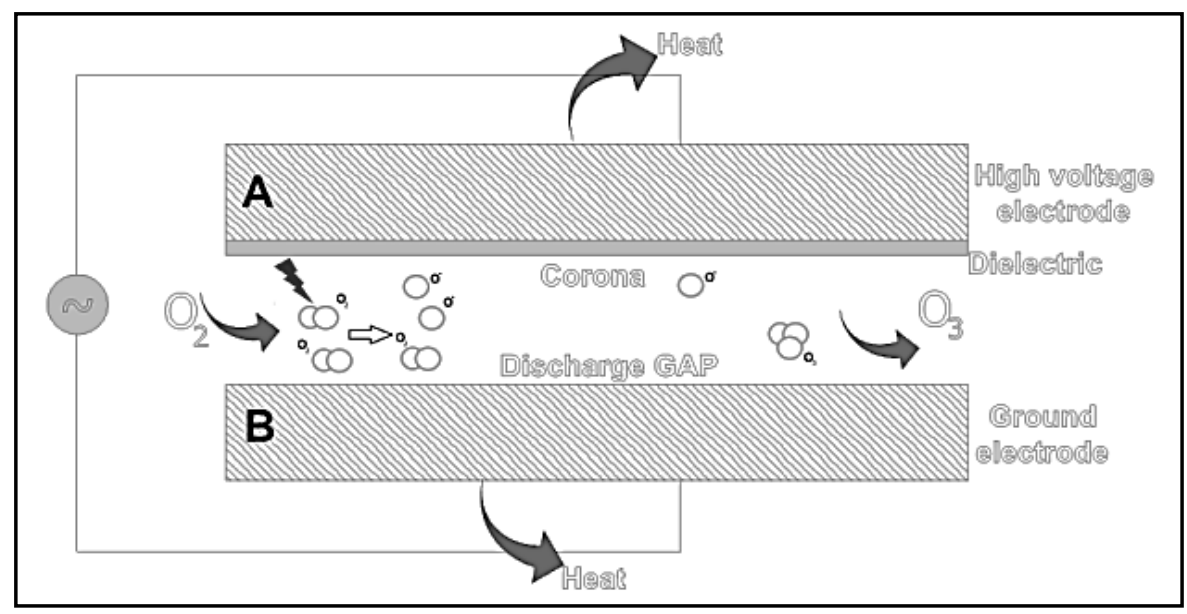

Figure 1. Ozone $\left(\mathrm{O}_{3}\right)$ generation: corona discharge 


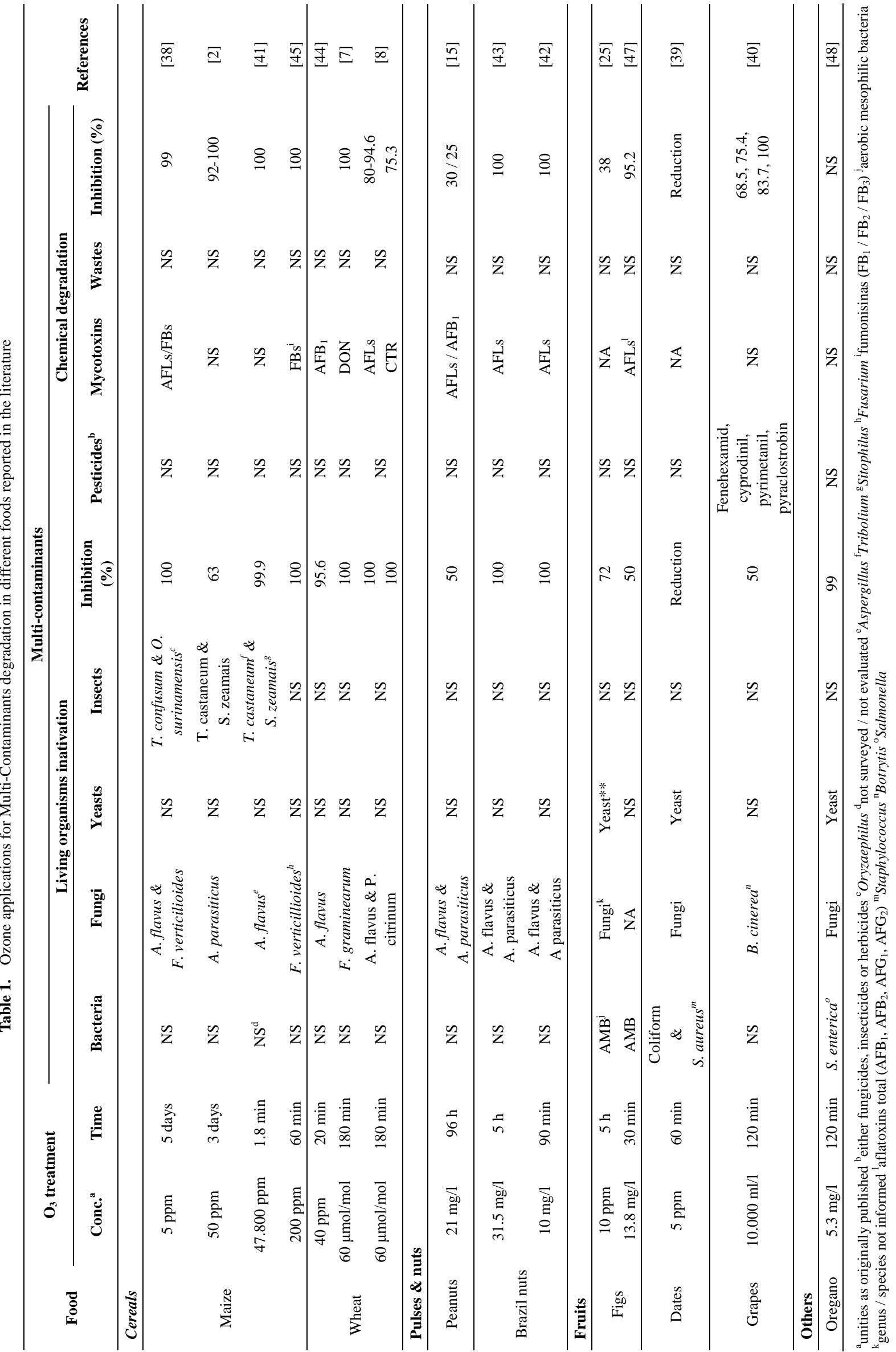




\subsection{Living Organisms}

Studies on ozonation against combinations of multiple living organisms (bacteria, yeast, fungi and/or insects) are reported mainly on fruits, cereals and spices.

Bacteria, yeast and fungi: Öztekin et al. [25] evaluated $\mathrm{O}_{3}$ application in figs at rate of $10 \mathrm{ppm}$ during $5 \mathrm{~h}$ and observed reduction of $72 \%$ of aerobic mesophilic bacteria (AMB), fungi and yeast. Also, Zorlugenç et al. [47] applied $\mathrm{O}_{3}$ in figs at rate of $13.8 \mathrm{mg} / \mathrm{l}$ during $30 \mathrm{~min}$, observing reduction of $50 \%$ in AMB and $95.2 \%$ of AFLs. Najafi and Khodaparast [39] applied the gas at rate $5 \mathrm{ppm}$ during $60 \mathrm{~min}$ in dates and reported reduction in bacteria (coliforms, Staphylococcus aureus), fungi and yeasts. In studies conducted to find the effect of $\mathrm{O}_{3}$ in spices (oregano), Torlak et al. [48] reported reduction of $99 \%$ of bacteria (Salmonella enteric), yeast and fungi when applied $5.3 \mathrm{mg} / \mathrm{l}^{-1}$ during 120 min. All authors, although report details of bacteria genera, do not specify fungi and yeasts. That is due to the fact that the aim was to inactivate all of them, despite their denomination details (Table 1).

Fungi and insects: in a study that evaluated the $\mathrm{O}_{3}$ fumigant efficacy (disinfestation - insects / and disinfection -fungi) in stored maize (8.9 tonnes - $350 \mathrm{bu}$ ) at $50 \mathrm{ppm}$ for 3 day, resulted in 92 to $100 \%$ mortality. That included the adults red flour beetle (Tribolium castaneum Herbst), maize weevil (Sitophilus zeamais Motsch.) and the Indian meal moth (Plodia interpunctella Hubner) at larval stage. The treatment also reduced by $63 \%$ the contamination of fungi (Aspergillus parasiticus Speare) on the kernel surface [2]. On the other hand, McDonough et al. [41] studied the concentration of $\mathrm{O}_{3}$ in the screw conveyor $(47,800 \mathrm{ppm})$ application in a short time (time average: $1.8 \mathrm{~min}$ ). Under these conditions, $100 \%$ mortality of $T$. castaneum Herbst \& S. zeamais Motsch and $96 \%$ reduction of $A$. flavus spores were observed in a single pass through the screw conveyor.

\subsection{Toxic Compounds Combined}

Despite of the studies related to multiple living organisms decontamination methods by $\mathrm{O}_{3}$, only a few have been reported on combination of multiple toxic compounds including pesticides and wastes in food.

However, food pesticide multi-degradation from their different Classes (organochlorines / organophosphorus / dithio- / carbamates / pyrethroids) and Groups (fungicides / insecticides / herbicides / among others) have been reported being degraded by $\mathrm{O}_{3}$. They are one of the main concerns regarding food safety of vegetable origin due to their commercial application during crops development in the field and will be mentioned here as multi-pesticides from different Classes: Fungicides - grapes fenehexamid, cyprodinil, pyrimetaniland pyraclostrobin, dithiocarbamate treated, had their residues degraded by $\mathrm{O}_{3}$ at $10 \mathrm{ppm}$ exposed during $60 \mathrm{~min}$. The reduction was $68.5,75.4$ and $83.7 \%$ for the three compounds, respectively [40]. Insecticides - when seeds (soft wheat, maize, dry wheat) were fenvalerate, methomyl, deltamethrin and fenitrothion contaminated and $\mathrm{O}_{3}$ treated (10-180 min, at 5-125 mg/l and 20-100 l/h flow) had quite effective reduction (up to 99\%) [49-52]. Insecticides $\mathrm{O}_{3}$ gas treated could be effectively reduced and degraded into non toxic by-products, especially for the rat liver functional interlinks [53, 54]. Herbicides - when bromoxinile and trifluralin were $\mathrm{O}_{3}$ treated at doses ranging from 80 to $480 \mu \mathrm{M}$ (10 min), the gas was able to significantly react with bromoxynil, achieving degradation of $98 \%$ (after $2 \mathrm{~min}$ ), however trifluralin was less $\mathrm{O}_{3}$ reactive, reaching only half (50\%) of its degradation after 5 min [55]. Toxic wastes - on the other hand, wastes that may be present in factories water effluents such as from wine distilleries (also pharmaceutical and textile industries), the $\mathrm{O}_{3}$ gas lead to living organisms inactivation and toxic compounds degradation thus thus can be a quite beneficial to nature and the humans safety in the area [20, 31, 34, 56-59].

\subsection{Living Organisms \& Toxic Compounds}

Regarding combination of multiple living organisms and toxic compounds decontamination methods reported in the literature, they were in the following combinations.

Fungi and mycotoxins: concentrations of $\mathrm{O}_{3}$ gas to be applied for both fungi \& toxins vary quite widely among the authors, such as low as $5 \mathrm{ppm}$, for a long exposure period such as 5 days, which can inhibit 100\% of fungi (Aspergillus flavus and Fusarium verticillioides) and AFLs in maize, carried out by Mason et al. [38]. Mylona et al. [45] also studied $\mathrm{O}_{3}$ application in maize, at $200 \mathrm{ppm}$ during $60 \mathrm{~min}$, obtained $100 \%$ of $A$. parasiticus inativation and $\mathrm{FB}_{1} / \mathrm{FB}_{2} / \mathrm{FB}_{3}$ degradation. As far as wheat is concerned, El-Desouky et al. [44] observed a reduction of $95.6 \%$ in the A. flavus infection and $100 \%$ degradation of $\mathrm{AFB}_{1}$. In another study with wheat, $F$. graminearum growth was totally inhibited after $180 \min$ of $\mathrm{O}_{3}$ exposition at 60 $\mu \mathrm{mol} / \mathrm{mol}$ and so DON contamination. In addition, the same authors, showed that the A. flavus growth was totally inhibited under those conditions [7]. Same research group reported that AFLs levels significantly decreased after 180 $\min$ at $60 \mu \mathrm{moL} / \mathrm{moL}(94.6,84.5,80.0$ and $81.0 \%$ of reduction for $\mathrm{AFB}_{1}, \mathrm{AFB}_{2}, \mathrm{AFG}_{1}$ and $\mathrm{AFG}_{2}$, respectively) and so $A$. flavus growth. The total inhibition of $P$. citrinum growth occurred also after $\mathrm{O}_{3}$ treatment longest time (180 min of exposure). In this same study, the CTR levels reduced after $\mathrm{O}_{3}$ treatment in both concentrations (40 and 60 $\mu \mathrm{moL} / \mathrm{moL}$ ) after $180 \mathrm{~min}$ of exposure [8]. Regarding nuts, the application of $\mathrm{O}_{3}$ in Brazil nut in studies of Scussel et al. [42] and Giordano et al. [43] at rate of 10 and $31.5 \mathrm{mg} / \mathrm{l}$ during 1.5 and 5 h obtained $100 \%$ of A. flavus, A. parasiticus and AFLs decontamination.

Fungi and fungicides: Gabler et al. [40] applied $\mathrm{O}_{3}$ in grapes during $2 \mathrm{~h}$ at rate of $10.000 \mathrm{ml} / \mathrm{l}$, aiming to remove Botrytis cinerea and fungicides (fenehexamid, cyprodinil, pyrimetanil and pyraclostrobin). Authors reported that the treatment reduced in $50 \%$ the fungi and up to $100 \%$ the 
fungicides.

Insect, fungi and mycotoxins: Mason et al. [38] applied 5 ppm during 5 days through maize grains aiming to destroy fungi (A. flavus and $F$. verticilioides), insect (T. confusum and Oryzaephilus surinamensis) and mycotoxins. Authors observed 100\% elimination of fungi and insect and $99 \%$ of AFLs degradation.

Regarding $\mathrm{O}_{3}$ gaseous effects on food composition, seed germination and/or its safety, several studies have reported its Green performance [9].

\section{Ozone Gas Parameters for Food Decontamination Efficiency}

Among the food types that have been efficiently $\mathrm{O}_{3}$ treated and being reported in the literature are those of vegetables and animal origin (either, raw, dry or processed). The application parameters (concentration and exposure time) vary according to the food protection (decontamination) purposes, i.e., whether for living organisms inactivation and/or toxic compounds degradation.

Due to the literature $\mathrm{O}_{3}$ diversity on decontamination parameters, several points need to be considered and paid attention prior the choice of adequate and efficient method of $\mathrm{O}_{3}$ application in food as follows. (a) Doses and contamination levels: the gas application methodology can be efficient, in (a.1) a single or may need multiple $\mathrm{O}_{3}$ doses; including (a.2) adjustments on its concentration according to the extent/intensity (load/level) of living organisms / toxic compounds to be destroyed, and/or the food group to be treated [42, 43, 60-63]. (b) Time: however, the efficacy of $\mathrm{O}_{3}$ application depends also on other factors, such as the (b.1) time of exposure; (b.2) humidity and (b.3) temperature during the procedure $[7,8,41]$. Food characteristics $x$ chamber size - in addition, the food (b.4) characteristics (whether with or without - husk/pericarp/testae/shell; in small or large particles - ground/whole) and the (b.5) container capacity and size, play important roles on the efficiency of the treatment gas conditions to be chosen and applied, which should be adjusted for adequacy. (c) Environment: another point to be considered for $\mathrm{O}_{3}$ best application is whether the food is present in bulk (loose) or separated in bags (small / large packages). Static or in motion - whether the gas is applied in static (inside ship containers or silos) food amount/quantity or in movement (conveyor transport belt / loading screw or during food storage load/unloading onto ship, train, container, truck). (d) State of food matrix: for raw (dry cereal / pulses / nuts / fruits - low humidity) or fresh (minimally processed vegetables sliced / chopped / peeled - high humidity) food, the application need attention on gas concentration and time adjustments [7, 8, 38, 41, 42, 47, 60, 61, 64-66].

\section{Ozone Gas Parameters for Food Decontamination Efficiency}

When deciding to apply an $\mathrm{O}_{3}$ gas decontamination method, one needs to know on how the gas concentration (to be achieved), will be measured and confirmed in the chamber and micro-environment surrounding the food. Despite of several methods (physical, physicochemical and chemical methods) that are reported for $\mathrm{O}_{3}$ measurement, there are differences and efficiencies to be considered among them:

\subsection{Gas Concentration Measuring}

The (a) Physical methods, (a.1) measure its absorption (directly in the UV, visible or infrared spectrum region) and the (a.2) quantify the products released (when $\mathrm{O}_{3}$ reacts with a chemical reagent such as potassium iodide for example). In the (b) Iodometric method, that has been approved by the International $\mathrm{O}_{3}$ Association [67], $\mathrm{O}_{3}$ oxidizes the iodide ions releasing iodine; that is then titrated with sodium thiosulfate to a starch endpoint. This method measures, apart from $\mathrm{O}_{3}$, also other formed oxidizing species (from the $\mathrm{O}_{3}$ decomposition solution $-{ }^{-} \mathrm{O}_{3}{ }^{-}, \mathrm{HO}_{2}{ }^{\cdot}$, and ${ }^{\circ} \mathrm{O}_{2}{ }^{-}$), hence, the measurement of residual $\mathrm{O}_{3}$ cannot be accurately done [13, 14]. However, the most commonly used is the (c) Indigo method, which is precise, fast and sensitive (low detection: $0.005 \mu \mathrm{g} / \mathrm{ml}$ ) [68]. As the indigo solution reacts additively with the $\mathrm{C}=\mathrm{C}$ bound (of the sulfonated indigo dye) causing its discoloration, that color changing is measured spectrophotometrically. It is not compromised, neither by the hydrogen peroxide, organic peroxide, mangans ions and oxidase species presence in the sample. Compared to the Iodometric, the Indigo Method is more suitable for measuring $\mathrm{O}_{3}$ residual $[9,13,14]$.

\subsection{Measuring Instruments}

Several manufactures produce instruments that measure $\mathrm{O}_{3}$ by determining the amount of UV light absorbed. Gaseous $\mathrm{O}_{3}$ absorbs short-UV wavelengths (maximum absorption at $253.7 \mathrm{~nm}$ ) with a gas-phase absorption coefficient of $3000+30 \mathrm{~m}^{-1} \mathrm{~cm}^{-1}$ (at $273{ }^{\circ} \mathrm{K}$ and 1 atm) [67]. On the other hand, the Calorimetric Methods depend upon the $\mathrm{O}_{3}$ decomposition in presence of a catalyst producing heat. Instruments using amperometric methods to measure the oxidation-reduction potential of $\mathrm{O}_{3}$ are available commercially [13, 14].

\section{Conclusions}

From the studies and data reported, $\mathrm{O}_{3}$ has shown its efficacy as a Green agent against combined multi-contaminants (present in the same application method). 
It is possible to obtain safe food through $\mathrm{O}_{3}$ gas decontamination, as long as the adequate conditions are observed and considered (regarding the food matrix, its surrounding environment, the contamination level and humidity present) in the application to be utilized and/or developed.

\section{REFERENCES}

[1] Sarig, P., Zahavi, T., Zutkhi, Y., Yannai, S., Lisker, N., BenArie, R., 1996, Ozone for control of post-harvest decay of table grapes caused by Rhizopus stolonifer, Physiol. Mol. Plant Pathol., 48(6): 403-415.

[2] Kells, S. A., Mason, L. J., Maier, D. E., Woloshuk, C. P., 2001, Efficacy and fumigation characteristics of ozone in stored maize, J. Stored Prod. Res., 37(4): 371-382.

[3] Sharma, R. R., Demirci, A., Beuchat, L. R., Fett, W. F., 2003, Application of ozone for inactivation of Escherichia coli O157:H7 on inoculated alfalfa sprouts, J. Food Proc. Preserv., 27(1): 51-64.

[4] Di Renzo, G. C., Altieri, G., D'Erchia, L., Lanza, G., Strano, M. C., 2005, Effects of gaseous ozone exposure on cold stored orange fruit. Proceedings of the 5th International Postharvest Symposium, edited by Mencarelli, F., and Tonutti, P., Vol 1-3.

[5] Bataller, M., Gonzalez, J. E., Veliz, E., Fernandez, L. A., 2012, Ozone applications in the post-harvest of papaya (Carica papaya L.): An alternative to amistar fungicide, Ozone-Sci. Eng., 34(3): 151-155.

[6] Savi, G. D., and Scussel, V. M., 2014, Effects of ozone gas exposure on toxigenic fungi species from Fusarium, Aspergillus, and Penicillium genera, Ozone Sci. Eng., 36(2): 144-152.

[7] Savi, G. D., Piacentini, K. C., Bittencourt, K. O., Scussel, V. M., 2014a, Ozone treatment efficiency on Fusarium graminearum and deoxynivalenol degradation and its effects on whole wheat grains (Triticum aestivum L.) quality and germination, J. Stored Prod. Res., 59: 245-253.

[8] Savi, G. D., Piacentini, K. C., Scussel, V .M., 2014b, Ozone treatment efficiency in Aspergillus and Penicillium growth inhibition and mycotoxin degradation of stored wheat grains (Triticum aestivum L.), J. Food Proc. Preserv., 39(6): 940-948.

[9] Christ, D., Savi, G. D.; Scussel, V. M., 2016, Efectiveness of ozone gas in raw and processed food for fungi and mycotoxin decontamination - A Review, J Chem. Biol. Phys. Sci., 6(2): 326-348.

[10] Rideal, E. K., 1920, Ozone, 1 Ed. London: Constable \& Publisher LTD, p. 198.

[11] Odling, F. R. S., 1872, On the history of ozone, Chem. News J Ind. Sci., 25-26:281-283.

[12] Mennad, B., Harrache, Z., Amir Aid, D., Belasri, A., 2010, Theoretical investigation of ozone production in negative corona discharge, Curr. Appl. Phys., 10(6):1391-1401.
[13] Khadre, M. A., and Yousef, A. E., 2001a, Decontamination of a multilaminated aseptic food packaging material and stainless steel by ozone, J. Food Saf., 21(1): 1-13.

[14] Khadre, M. A., Yousef, A. E., Kim, J. G., 2001b, Microbiological aspects of ozone applications in food: A review, J. Food Sci., 66(9):1242-1252.

[15] Alencar, E. R. d., Faroni, L. R. D., Martins, M. A., Costa, A. R. d., Cecon, P. R., 2011, Decomposition kinetics of gaseous ozone in peanuts, Eng. Agric., 31(5): 930-939.

[16] Xu, L. J., 1999, Use of ozone to improve the safety of fresh fruits and vegetables, Food Technol., 53(10): 58-61.

[17] Kim, J. G., and Yousef, A. E., 2000, Inactivation kinetics of foodborne spoilage and pathogenic bacteria by ozone, J. Food Sci., 65(3): 521-528.

[18] Sharma, R. R., Demirci, A., Beuchat, L. R., Fett, W. F., 2002, Inactivation of Escherichia coli O157:H7 on inoculated alfalfa seeds with ozonated water and heat treatment, J. Food Prot., 65(3): 447-451.

[19] Sharma, R. R., Demirci, A., Puri, V. M., Beuchat, L. R., Fett, W.F., 2004, Modeling the inactivation of Escherichia coli O157:H7 on inoculated alfalfa seeds during exposure to ozonated or electrolyzed oxidizing water, Trans. Asae, 47(1): 173-181.

[20] Tatapudi, P., and Fenton, J. M., 1994, Electrochemical oxidant generation for wasterwater treatment, in: J. Electroanal. Chem., edited by Sequeira, C.A.C., Amsterdam: Elsevier.

[21] Armor, J. N., 1999, Striving for catalytically green processes in the 21st century, App. Catal. A: General., 189(2): 153-162.

[22] Restaino, L., Frampton, E. W., Hemphill, J. B., Palnikar, P., 1995, Efficacy of ozonated water against various food-related microorganisms, Appl. Environ. Microbiol., 61(9): 3471-3475.

[23] Perez, A. G., Sanz, C., Rios, J. J., Olias, R., Olias, J. M., 1999, Effects of ozone treatment on postharvest strawberry quality, J. Agric. Food Chem., 47(4):1652-1656.

[24] Palou, L. S., Crisosto, C. H., Smilanick, J. L., Adaskaveg, J. E., Zoffoli, J. P., 2002, Effects of continuous 0.3 ppm ozone exposure on decay development and physiological responses of peaches and table grapes in cold storage, Postharvest Biol. Technol., 24(1): 39-48.

[25] Öztekin, S., Zorlugenç, B., Zorlugenç, F. K., 2006, Effects of ozone treatment on microflora of dried figs, J. Food Eng., 75(3): 396-399.

[26] Cullen, P. J., Tiwari, B. K., O'Donnell, C. P., Muthukumarappan, K., 2009, Modelling approaches to ozone processing of liquid foods, Trends in Food Sci. Technol., 20(3-4): 125-136.

[27] Keun, W. C., and Kang, J., 2011, Study on water treatment improvement measures based on case studies of ozone disinfection at domestic water treatment plants, J. Korean Soc. Water Wastewater., 25(2):153-160.

[28] Sarron, E., Cochet, N., Gadonna-Widehem, P., 2013, Effects of aqueous ozone on Pseudomonas syringae viability and ice nucleating activity, Proc. Biochem., 48(7):1004-1009. 
[29] Ong, K. C., Cash, J. N., Zabik, M. J., Siddiq, M., Jones, A. L., 1996, Chlorine and ozone washes for pesticide removal from apples and processed apple sauce., Food Chem., 55(2): 153-160.

[30] Hwang, E. S., Cash, J. N., Zabik, M. J., 2001, Postharvest treatments for the reduction of mancozeb in fresh apples, J. Agric. Food Chem., 49(6):3127-3132.

[31] Kunz, A., Peralta-Zamora, P., de Moraes, S. G., Duran, N., 2002, New tendencies on textile effluent treatment, Quim. Nova, 25(1):78-82.

[32] Ternes, T. A., Stuber, J., Herrmann, N., McDowell, D., Ried, A., Kampmann, M., Teiser, B., 2003, Ozonation: a tool for removal of pharmaceuticals, contrast media and musk fragrances from wastewater?, Water Res., 37(8):1976-1982.

[33] Mendez, F., Maier, D. E., Mason, L. J., Woloshuk, C. P., 2003, Penetration of ozone into columns of stored grains and effects on chemical composition and processing performance, J. Stored Prod. Res., 39(1): 33-44.

[34] Almeida, E., Regina, M., Rosa, M. A., Duran, N., 2004 Wastewater treatment by oxidation with ozone, Quim. Nova, 27(5): 818-824.

[35] Bagher-Ebadian, H., 2011, Ozone, in: Green Health: An A-to-Z, Ogunseitan, O. and Robbins, P. (Editors). Thousand Oaks, CA: SAGE Publications, p. 340-343.

[36] USEPA., 1999, Alternative disinfectants and oxidants guidance manual: United States Environ. Prot. Ag. EPA 815-R-99-014.

[37] UTALCA., 2017, New system to decontaminate Food and Water. Universidad de Talca. [Online]. Available: www.utalca.cl/english/noticias/05_2017.html.

[38] Mason, L. J., Woloshuk, C. P., Maier, D. E., 1997, Efficacy of ozone to control insects, molds and mycotoxins, in: Donahaye, E.J., Navarro, S., Varnava, A., editors. Proceedings of the International Conference on Controlled Atmosphere and Fumigation in Stored Products, Nicosia, Cyprus: Printco Ltd. p. 665-670.

[39] Najafi, M. B. H., Khodaparast, M. H. H., 2009, Efficacy of ozone to reduce microbial populations in date fruits, Food Control, 20(1): 27-30.

[40] Gabler, F. M., Smilanick, J. L., Mansour, M. F., Karaca, H., 2010, Influence of fumigation with high concentrations of ozone gas on postharvest gray mold and fungicide residues on table grapes, Postharvest Biol. Technol., 55(2): 85-90.

[41] McDonough, M. X., Campabadal, C. A., Mason, L. J., Maier, D. E., Denvir, A., Woloshuk, C., 2011, Ozone application in a modified screw conveyor to treat grain for insect pests, fungal contaminants, and mycotoxins, J. Stored Prod. Res., 47(3): $249-254$

[42] Scussel, V. M., Giordano, B. N., Simao, V., Manfio, D., Galvao, S., Ferreira Rodrigues, M.N., 2011, Effect of oxygen-reducing atmospheres on the safety of packaged shelled brazil nuts during storage, Intl. J. Anal. Chem., 2011: $1-9$.

[43] Giordano, B. N. E., Nones, J., Scussel, V.M., 2012, Susceptibility of the in-shell Brazil nut mycoflora and aflatoxin contamination to ozone gas treatment during storage, J. Agric. Sci., 4(8): 1-10.
[44] El-Desouky, T. A., Sharoba, A. M. A., El-Desouky, A. I., El-Mansy, H. A., Naguib, K., 2012, Evaluation of ozone gas as an anti-aflatoxin B1 in wheat grains during storage, J. Agroalim. Proc. Technol., 18(1): 13-19.

[45] Mylona, K., Kogkaki, E., Sulyok, M., Magan, N., 2014, Efficacy of gaseous ozone treatment on spore germination, growth and fumonisin production by Fusarium verticillioides in vitro and in situ in maize, J. Stored Prod. Res., 59:178-184.

[46] Scussel, V. M., Giordano, B. N. E., Beber, M., Savi, G. D., Christ, D., 2016, Field and storage fungi inactivation and mycotoxins degradation by ozone gas in grains and nuts, in: Navarro, S., Jayas, D., Alagusundaram, K. Proceedings of the $10^{\text {th }}$ International Conference on Controled Atmosphere and Fumination in Stored Products, New Delhi, 11/2016, Session 4, p. 225-228.

[47] Zorlugenç, B., Kıroğlu Zorlugenç, F., Öztekin, S., Evliya, I.B., 2008, The influence of gaseous ozone and ozonated water on microbial flora and degradation of aflatoxin B1 in dried figs, Food Chem. Toxicol., 46(12): 3593-3597.

[48] Torlak, E., Sert, D.,Ulca, P., 2013, Efficacy of gaseous ozone against Salmonella and microbial population on dried oregano, Int. J. Food Microbiol., 165(3): 276-280.

[49] Ikeura, H., Kobayashi, F., Tamaki, M., 2011, Removal of residual pesticide, fenitrothion, in vegetables by using ozone microbubbles generated by different methods, J. Food Eng., 103(3): 345-349.

[50] Tran, N. T. T., Trinh, T. H., Hoang, N. M. Ngo, T. M., 2014, UV/Ozone Treatment of the Pyrethroid Insecticide Fenvalerate in Aqueous Solutions, APCBEE Procedia, 8: 151-155.

[51] Chang, C. C., Trinh, C., Chiu, C. Y., Chang, C. Y., Chiang, S. W., Ji, D. R., Tseng, J. Y., Chang, C. F., Chen, Y. H., 2015, UV-C irradiation enhanced ozonation for the treatment of hazardous insecticide methomyl, J. Taiwan Inst. Chem. Eng., 49: $100-104$

[52] Savi, G. D., Piacentini, K. C., Scussel, V. M., 2015, Reduction in residues of deltamethrin and fenitrothion on stored wheat grains by ozone gas, J. Stored Prod. Res., 61: 65-69.

[53] Masten, S. J., Tian, M., Upham, B. L., Trosko, J. E., Trosko, E., 2001, Effect of selected pesticides and their ozonation by-products on gap junctional intercellular communication using rat liver epithelial cell lines, Chemosphere, 44(3): 457-465.

[54] Wu, J., Lan, C., Chan, G. Y. S., 2009, Organophosphorus pesticide ozonation and formation of oxon intermediates, Chemosphere, 76:1308-1314.

[55] Chelme-Ayala, P., El-Din, M. G., Smith, D. W., 2010, Kinetics and mechanism of the degradation of two pesticides in aqueous solutions by ozonation, Chemosphere, 78(5): 557-562.

[56] Gulyas, H., Bismarck, R. von., Hemmerling, L., 1995, Treatment of industry wastewaters with ozone/hydrogen peroxide, Water Sci. Technol., 32(7): 127-134.

[57] Balcioğlu, I. A., and Arslan, I., 2001, Partial oxidation of reactive dyestuffs and synthetic textile dye-bath by the $\mathrm{O} 3$ and O3/H2O2 processes, Water Sci. Technol., 43(2): 221-8. 
[58] Beltran-Heredia, J., Torregrosa, J., Dominguez, J. R. Peres, J. A., 2001, Kinetics of the reaction between ozone and phenolic acids present in agro-industrial wastewaters, Water Res., 35(4): 1077-1085.

[59] Gogate, P. R., and Pandit, A. B., 2004, A review of imperative technologies for wastewater treatment I: oxidation technologies at ambient conditions, Adv. Environ.Res., 8(3-4): 501-551.

[60] McKenzie, K. S., Kubena, L. F., Denvir, A. J., Rogers, T. D., Hitchens, G. D., Bailey, R. H., Harvey, R. B., Buckley, S. A., Phillips, T. D., 1998, Aflatoxicosis in turkey poults is prevented by treatment of naturally contaminated corn with ozone generated by electrolysis, Poultry Sci., 77(8): 1094-1102.

[61] Inan, F., Pala, M., Doymaz, I., 2007, Use of ozone in detoxification of aflatoxin B1 in red pepper, J. Stored. Prod. Res., 43(4): 425-429.

[62] Diao, E., Hou, H., Chen, B., Shan, C., Dong, H., 2013, Ozonolysis efficiency and safety evaluation of aflatoxin B1 in peanuts, Food Chem. Toxicol., 55: 519-525.
[63] Luo, X., Wang, R., Wang, L., Li, Y., Bian, Y.,Chen, Z. 2014. Effect of ozone treatment on aflatoxin B1 and safety evaluation of ozonized corn, Food Control, 37: 171-176.

[64] Maeba, H., Takamoto, Y., Kamimura, M., Miura, T., 1988, Destruction and detoxification of aflatoxins with ozone, J. Food Sci., 53(2): 667-668.

[65] McKenzie, K. S., Sarr, A. B., Mayura, K., Bailey, R. H., Miller, D. R., Rogers, T. D., Norred, W. P., Voss, K. A., Plattner, R. D., Kubena, L. F., Phillips, T. D., 1997, Oxidative degradation and detoxification of mycotoxins using a novel source of ozone, Food Chem. Toxicol., 35(8): 807-820.

[66] Prudente Jr, A.D., and King, J. M., 2002, Efficacy and safety evaluation of ozonation to degrade aflatoxin in corn, J. Food Sci., 67(8): 2866-2872.

[67] Gordon, G., and Grunwell, J., 1983, in: Municipal Wastewater Disinfection, Proceedings of Second National Symposium, Orlando, Florida, EPA-600/9-83-009, US Environmental Protection Agency, Cincinnati, Ohio.

[68] Bader, H., and Hoigné, J., 1981, Determination of ozone in water by the indigo method, Water Res., 15(4):449-456. 